\title{
THE PRINCIPLE OF INEVITABILITY AND THE INSTITUTION OF EXEMPTION FROM LEGAL LIABILITY: ASPECTS OF THE RELATIONSHIP
}

\author{
Anatolii Y. Shevchenko ${ }^{1}$ \\ Serhii V. Kudin ${ }^{2}$ \\ Oleksandr M. Loshchykhin ${ }^{3}$ \\ Vasyl H. Fatkhutdinov ${ }^{4}$
}

\begin{abstract}
The relevance of the research problem is due to the need for theoretical justification of the diversity of aspects of the relationship between the principles of inevitability and the institution of exemption from legal liability. The purpose of the article is to identify the essence of the relationship between the principles of inevitability and the institution of exemption from legal liability. The leading methodological approach of the research is the structural-functional approach, which allows to consider the principles of inevitability and the institution of exemption from legal liability as elements of the normative part of the legal system, which have their own functional purpose. The article reveals the essence of the principle of inevitability of legal liability; the content of the
\end{abstract} institute of exemption from legal liability is clarified; aspects of the relationship between the principle of inevitability of legal liability and the institution of exemption from legal liability have been established.

Keywords: legal system, legal responsibility, the principle of inevitability, the institution of exemption.

\section{INTRODUCTION}

Due to the spread of trends of humanization and democratization of the legal worldview, liberalization of legal practice in Ukraine, legal liability is no longer considered in a purely negative aspect. Scholars are increasingly turning to its positive features,

\footnotetext{
${ }^{1}$ Department of Theory, History of Law and State and Constitutional Law, University of the State Fiscal Service of Ukraine, 08205, 31 Universytetska Str., Irpin, Ukraine. E-mail: ashevchenko@ tanu.pro

${ }^{2}$ Department of Theory, History of Law and State and Constitutional Law, University of the State Fiscal Service of Ukraine, 08205, 31 Universytetska Str., Irpin, Ukraine.

${ }^{3}$ Department of Theory of State and Law and Constitutional Law, Interregional Academy of Personnel Management, 03039, 2 Frometivska Str., Kyiv, Ukraine.

${ }^{4}$ Department of Law Enforcement and Anti-Corruption, Interregional Academy of Personnel Management, 03039,

2 Frometivska Str., Kyiv, Ukraine.
} 
GÊNERO E

INTERDISCIPLINARIDADE

using a broad approach, analyzing its prospects in a democratized legal regime. Thus, legal responsibility becomes relevant as a means of influence, but in the context of recognizing its dualistic nature, which requires a revision of the structure of its principles, among which the principle of inevitability deserves special attention for its properties.

In modern law, various trends have emerged regarding the consideration of the principle of inevitability of legal liability. A group of researchers in the field of law gives great importance to the principle of inevitability of legal liability. Thus, the establishment of state responsibility for the commission of offenses should provide for its mandatory response as a manifestation of the principle of inevitability of responsibility for what is done, which is directly the principle of policy of any state (Sobolev and Potapenko, 1989). The principle of inevitability of legal responsibility should be the principle of legal policy of each state governed by the rule of law (Pomogalov, 2007).

New views on the principle of the inevitability of legal liability have recently emerged in Europe. It is seen as a principle of positive legitimacy, and its meaning is that the inevitability of liability is the best way to manifest the preventive effect of law. In Germany, for example, this principle is quite positively perceived by society and is
Vol no 02 | no 01 | ISSN: 2675-7451

https://www.periodicojs.com.br/index.php/gei/index

embodied in the principle of legality, which requires the prosecution of all perpetrators (Legataetspmzip). This principle is opposed to the principle of own discretion widely used in common law systems, which gives the prosecution the right to choose, based on their own awareness of expediency, among the probable defendants of some of them (Pomogalov, 2007; Babayev, 1999).

Another group of researchers, without discussing with opponents the principle of inevitability of legal liability, takes the position that this principle still remains the principle of current state legislation, and its absence in the structure of the principles of the Criminal Code is not fundamental. Thus, it is believed that the formation of the rule of law is directly related to strengthening law and order, strengthening control over crime, ensuring the inevitability of liability for offenses and full use in this activity of all laws so that no offender could escape punishment (Vasilieva, 2003).

It is also possible to distinguish a separate group of researchers of the principle of inevitability of legal liability, namely its critics or opponents. Thus, it is noted that not all law researchers pay conceptual attention to the absence of the principle of inevitability of legal liability in the system of principles of criminal law, that the absence of the current principle of inevitability of liability in modern law is not negative, because it as well as once the principle of inevitability of punishment 
GÊNERO E

INTERDISCIPLINARIDADE

ceased to correspond to the latest trends in legal policy, and with this approach will be more intensive approximation of national law to Western, which does not see in the responsibility something inevitable (Golovko, 1999; Baulin, 2013).

The lack of clear ideas about the existence of the principle of inevitability of both positive and negative liability, as well as a strong understanding that they are part of a single holistic legal phenomenon, necessitates the formulation within this article of the definition of the principle of inevitability of legal liability taking into account all the specific features of each of the forms of its implementation. The following methods were used in the research process: dialectical method, as well as a number of theoretical methods (analysis, synthesis, logical, systemic, structural, functional, prognostic, hermeneutic, comparative-legal, formal-dogmatic).

\section{GENERAL ASPECTS OF UNDERSTANDING THE CONCEPT OF LEGAL LIABILITY}

Usually, the category of legal liability is associated with the illegal behaviour of the subject of legal relations and the occurrence of adverse consequences in this regard. But recently, the legal literature has begun to draw attention to a broad, positive understanding of
Vol no 02 | no 01 | ISSN: 2675-7451

https://www.periodicojs.com.br/index.php/gei/index

legal responsibility, when the latter is seen as a social, moral and legal obligation of the individual, and therefore no one can be outside the law. It should be noted that in the study of this issue we will proceed from the understanding of the dualistic nature of legal responsibility, namely from the combination of its positive and negative aspects. Given that the law is characterized not only by prohibitive tendencies, but the development and formation of the rule of law determine the paramount importance of positive legal responsibility, which involves socially useful activity of people, it is important to prevent offenses so that there is no need to punish them. And it is positive legal responsibility that is necessary to stimulate an active life position through the provision of a wide range of rights.

In disclosing the essence of the principle of inevitability of legal liability should be based on an understanding of the dualistic nature of legal liability, and therefore it is unacceptable to consider it only in the context of the offense. This approach is due to the fact that the principle of inevitability should characterize legal liability as a whole, rather than individual aspects of its manifestation. We consider it expedient to dwell on the essence of the positive form of realization of legal responsibility, so that we can derive the common essential characteristics of the principle of inevitability of legal responsibility, which would be common to the 
GÊNERO E

INTERDISCIPLINARIDADE

both aspects of this responsibility. We are convinced of the need to distinguish between positive (voluntary) and negative (coercive) forms of legal liability because in this approach legal liability retains its integrity, is not divided into types or aspects, but is considered as a holistic legal phenomenon with various forms of manifestation or implementation. The essence of the forms of realization of legal responsibility is a duty, because without taking into account this legal category it is impossible to understand the essence and nature of legal responsibility (Korelsky and Perevalov, 2000).

The analysis of the current legislation shows that the leading importance is given to the voluntary form of realization of legal responsibility. For example, in the Basic Law of the state the term "responsibility" is used several times in a purely positive sense. Thus, the Preamble of the Constitution of Ukraine states that, realizing the responsibility before God, its own conscience, previous, present and future generations, the Verkhovna Rada of Ukraine on behalf of the Ukrainian people adopts this Constitution - the Basic Law of Ukraine. In Article 79 of the Constitution of Ukraine states that before taking office, MPs of Ukraine take an oath before the Verkhovna Rada of Ukraine, where they swear allegiance to Ukraine; undertake by all their actions to defend the sovereignty and independence of Ukraine, to care for the good of the Fatherland and the welfare of the Ukrainian people; to
Vol no 02 | no 01 | ISSN: 2675-7451

https://www.periodicojs.com.br/index.php/gei/index

abide by the Constitution of Ukraine and the laws of Ukraine, to perform their duties in the interests of all compatriots. Article 104 of the Constitution of Ukraine stipulates that the newly elected President of Ukraine, taking office, takes an oath, where he solemnly swears allegiance to Ukraine; undertakes to defend the sovereignty and independence of Ukraine in all its affairs, to care for the good of the Fatherland and the welfare of the Ukrainian people, to defend the rights and freedoms of citizens, to abide by the Constitution of Ukraine and laws of Ukraine, to fulfill its duties in the interests of all compatriots. In our opinion, the reference of the legislator to the duties of the President of Ukraine, MPs of Ukraine is a certain method of legal technique, by means of which their legal responsibility is indicated (Lazarev, 1999).

Voluntary form of legal liability, as well as coercive, has two stages: the first - static, characterized by the presence of the subject of legal relations of legal obligation; the second dynamic, is expressed in his lawful behaviour and the use of means of encouraging. Voluntary form of implementation of legal liability may have a procedural form of implementation, which will be manifested in the activities of competent authorities to establish signs of lawful conduct and the application of means of encouraging. The procedural form may consist in the activities of the competent authorities for the assigning of 
GÊNERO E

INTERDISCIPLINARIDADE

honorary titles and awards. In some cases, the establishment of normal citizen activity not linked to the encouragement, also can take this form. For example, this may be the activity of the investigator, the prosecutor in establishing the circumstances that exclude the criminality of the act. Usually, such cases end with the closure of the case for lack of the evidence of the offense or its fact. As a conclusion, it is noted that the citizen acted lawfully, i.e. the state states his voluntary (positive) responsibility.

It is possible to allocate essential characteristics of the voluntary form of realization of legal responsibility. Thus, the external side of its manifestation is characterized by the presence of such elements as lawful conduct, its actual results, positive legal consequences in the form of the application of incentive sanctions, time and place. The objective form of implementation of voluntary legal liability is a concept broader in content than the external side of its manifestation, and includes the obligation to commit certain acts provided by law, lawful acts, the causal link between behaviour and its consequences, positive legal consequences (application of incentive sanctions), place, time. The relationship between incentives and voluntary forms of legal liability is as follows: incentives are a measure of voluntary form of legal liability; legislative establishment of incentive measures is a normative
Vol no 02 | no 01 | ISSN: 2675-7451

https://www.periodicojs.com.br/index.php/gei/index

consolidation of a voluntary form of implementation; the application of incentives is the implementation of voluntary legal liability; voluntary legal liability can be exercised both before and after the commission of the offense. After committing an offense, a voluntary form of legal liability is manifested in the elimination of its negative consequences, in the form of a conscientious attitude to the performance of their duties while undergoing coercive measures, in exemption from the state coercive form of legal liability.

Given the above, we propose to consider the voluntary form of legal liability as a way to ensure the legal obligation (necessity) of the subjects of law to implement the provisions of legal norms, which is outwardly manifested in their lawful behaviour, which is encouraged and approved by the state; state-compulsory form of realization of legal responsibility as a way of legislative maintenance of necessity of performance by the offender of obligations concerning deprivation of certain social benefits in connection with application to it of coercive measures of negative influence. Positive legal responsibility is the conscientious performance of the subject of legal relations of its obligations to civil society, the rule of law, a group of people and an individual, and negative - a specific legal relationship between the state and the offender, resulting from the application of the latter measures of state and legal coercion, 
GÊNERO E

INTERDISCIPLINARIDADE

characterized by condemnation of the offense and the subject of the offense, imposing on the latter the obligation to suffer deprivation and adverse consequences of a personal, property or organizational nature. Thus, due to the objectively existing dependence on the state, the subject of legal relations is obliged to comply with the instructions and comply with the prohibitions provided by law.

It is necessary to pay attention to the existence of two types of coercion in the case of legal prosecution: coercion to comply with regulatory requirements and coercion to suffer the negative consequences established by the rule of law. If the first type of coercion is the purpose of retrospective legal responsibility, the second - a way to realize the social purpose of responsibility, to achieve its goals. The essence of retrospective legal liability is the coercion of a person through the application of measures of state coercion to comply with regulatory requirements, i.e. to lawful and responsible behaviour. We can say that retrospective responsibility is the same positive responsibility, only under the influence of coercion; the same performance of duty, but in a state of coercion. The common features of both forms of legal liability include normativeness, formal certainty, legal security and guarantee, phasing, and so on.

It is necessary to dwell on the consideration of the subjective obligation to be influenced by measures of legal responsibility.
Vol no 02 | no 01 | ISSN: 2675-7451

https://www.periodicojs.com.br/index.php/gei/index

If we consider the negative form of legal liability, this obligation, first of all, will be expressed in the inevitable obligation of the offender to suffer the negative consequences of restricting his rights, freedoms and legitimate interests. The degree of restrictions is directly proportional to the degree of public danger of the offense and the measure of legal responsibility. An essential feature of this obligation is that when the rights and freedoms of the offender are restricted, the will or unwillingness of the offender is not taken into account at all. In addition, their strict and unavoidable execution may be defined as an additional obligation for the offender. The principle of inevitability forms the basis of this obligation, which applies to all cases of compliance with the requirements of legal norms, and situations of their violation. The imposition and performance of a duty must be unavoidable and secured by the state, because only in this case can we speak of lawful conduct that will express the responsibility of the subject. Inevitability involves a combination of persuasion and coercion aimed at ensuring the fulfillment of a duty.

The effectiveness of legal liability is not manifested in its cruelty or rigidity, but in its inevitability. Indeed, inevitability is a key principle of legal responsibility, a kind of engine of the process of implementation of its measures, the implementation of which contributes to the goals of legal responsibility 
GÊNERO E

INTERDISCIPLINARIDADE

in general and fulfills the tasks of general and special crime prevention in particular. Also, compliance with this principle in combination with others ensures the implementation of such a function of legal responsibility as increasing the authority of the law, law enforcement agencies and maintaining law and order in the state and so on. The principle of the inevitability of legal liability was usually seen as the duty of the state to respond to offenses; to bring the offender to justice; the duty of the offender to be adversely affected in the form of conviction, deprivation of property or personal character. These aspects of the principle of inevitability of legal liability help to better reveal its close relationship with the functions of legal liability, namely: punitive, educational, restorative, etc.

In our deep conviction, the main disadvantage of all approaches is a one-sided, purely retrospective approach to understanding the essence of legal responsibility, and, as a consequence, awareness of the principle of inevitability of legal responsibility, which does not meet modern trends in legal understanding. This situation has arisen due to the fact that many experts in the field of the theory of law, the existence of a positive aspect of legal liability has been questioned or even denied. Traditionally, in public opinion, liability was associated with retribution, punishment, and the problem of legal liability was dealt with mainly by lawyers who were primarily
Vol no 02 | no 01 | ISSN: 2675-7451

https://www.periodicojs.com.br/index.php/gei/index

interested in criminal liability. This may be because the understanding of law in public opinion and science was focused on obligations, prohibitions, and state coercive measures.

Of course, the state of law must respond to every offense committed, which will consist in bringing the offender to justice and restoring the broken social relations. If after committing an offense against the guilty person measures of legal responsibility are not applied, it gives the impression of the admissibility of illegal behaviour, there is confidence in the impunity of further illegal actions by the offender and others. In this case, the punishment of the offender as an inevitable reaction of the state is not its end in itself, but is carried out for the second and main aspect of inevitability - not a violation of the legal relationship imposed on him in the future. The inevitability of legal liability should be manifested not only in the negative reaction of the state to the offense, but also in the preventive effect on the offender. As a result of the implementation of the punitive function of legal liability, the offender is subject to certain restrictions on their rights and interests, thus losing the opportunity to commit new offenses. Consequently, there is an inevitability of private-preventive influence on the offender.

In our opinion, the definition of inevitability as a mandatory response, impact or negative assessment of the offense is rather 
vague. Defining the mandatory disclosure of the offense as a sign of the inevitability of legal liability, leads to its identification with the basic principles of procedural and operationalinvestigative activities. But we consider the inevitability of legal liability as a principle of substantive rather than procedural law. Therefore, the mandatory disclosure of an offense cannot be considered as a principle of legal liability, but it can become one of the main principles of the legal process. Of course, the inevitability of legal liability and inevitability as a mandatory disclosure of the offense are interrelated, and usually it is through the disclosure of the offense ensures the inevitability of liability, but it should be noted that they lie in different legal areas substantive and procedural law, respectively.

It is impossible to agree with the interpretation of the inevitability of responsibility as a mandatory application of the sanction of the rule of law, the mandatory imposition of punishment, because in this approach the problem of inevitability is narrowed, reduced to the inevitability of punishment, not responsibility. Given that the concepts of responsibility and punishment are not identical, so the inevitability of responsibility and the inevitability of punishment are completely different in essence and nature concepts. The principle of inevitability of legal liability can be considered through incentive measures, as their
Vol no 02 | no 01 | ISSN: 2675-7451

https://www.periodicojs.com.br/index.php/gei/index

application is provided by law for the commission by the subject of the right of a socially useful act related to the excessive performance of his legal obligations. The state, represented by its authorized bodies, must respond to both offenses and socially useful acts

We take the position that it is inappropriate to link the inevitability of legal liability with punishment. This principle is not limited to the obligatory reaction of the state to the committed offense, its disclosure, exposure of the offender, etc. The principle of inevitability should be explored through the category of mutual responsibility. After all, the state itself, being a participant in legal relations, bears legal responsibility to society and citizens. In a state governed by the rule of law, the subjects of legal relations must be bound by mutual responsibility, where lawful conduct must be inevitably ensured both for citizens and for the state itself, as it is the result of the principle of inevitability of legal responsibility. We can talk about the implementation of the principle of inevitability of legal liability only if the imposition of legal obligations on the subjects of law and ensuring their implementation will be inevitable due to their clear legal regulation and strict control by the state.

The essence of the state-coercive form of realization of legal responsibility is the obligation to be subject to deprivation of 
GÊNERO E

INTERDISCIPLINARIDADE

property or non-property character, and condemnation, actual deprivation are optional features of this legal phenomenon. So we can't talk about their inevitability. The obligation to be deprived arises simultaneously with the commission of the offense by the person, because it is at that moment that the static stage of legal liability arises. In our opinion, the principle of inevitability of legal liability should be associated not only with the statecompulsory, but also with the voluntary form of implementation of the latter, because the inevitability of liability in the long run remains in all cases.

Consider the principle under study in connection with its direct legislative consolidation. Thus, the principle of inevitability of criminal liability is manifested in the fact that according to criminal law, crimes are recognized only as punishable acts, and in all the rules that determine the composition of specific crimes, there are sanctions, which determine the type and degree of punishment. The existence of the principle of inevitability of criminal liability is evidenced by the tasks of criminal liability. According to Article 1, the task of the Criminal Code of Ukraine is to ensure the legal protection of human and civil rights and freedoms, property, public order and public safety, the environment, the constitutional order of Ukraine from criminal encroachment, peace and security, and crime prevention. To
Vol no 02 | no 01 | ISSN: 2675-7451

https://www.periodicojs.com.br/index.php/gei/index

accomplish this task, the Criminal Code of Ukraine determines which socially dangerous acts are crimes and which punishments are applied to the perpetrators. Also, the inevitability of liability follows from the purposes of criminal liability and punishment. According to Article 50 of the Criminal code of Ukraine, the punishment aims not only at punishment, but also correction of convicts, and also prevention of commission of new crimes both by convicts, and other persons. By the way, it should be borne in mind that the provision of private prevention directly depends on bringing the perpetrators to justice.

The implementation of the principle of inevitability of legal liability in bringing to civil liability has certain features, as the latter depends on the will of the injured party. It must be agreed that the inevitability of liability under civil law has its own specifics, but this does not preclude its existence. Indeed, civil liability depends on the will of the injured party, but the obligation of the guilty person to apply legal measures arises inevitably, another thing is that its implementation depends on certain circumstances. The specificity of the manifestation of the principle of inevitability of legal liability in civil liability is not that this principle is not typical for it, but that it is the obligation of the state to prosecute the offender in case of will of the victim, to strengthen the liability of legal entities, in particular, and civil liability in general. Therefore, if the person 
GÊNERO E

INTERDISCIPLINARIDADE

whose rights have been violated has applied to the competent authorities for legal protection, they must take all measures provided by law to bring the offender to justice. The principle of inevitability of legal liability for offenses has long been a stumbling block for all legal science and practice. The rapid development of the theory and practice of the application of traditional sectoral measures of legal responsibility convinces us that not all of them are effective, and quite often do not achieve their goals.

Assuming that the application of measures of legal responsibility is always appropriate, in this case it would be necessary to exclude from the legislation of our state the institutions of exemption from legal responsibility and punishment. We proceed from the position that the application of these measures is not always appropriate. If the law enforcer establishes that the goals of legal liability can be achieved without the application of measures of legal liability, the subject is released from legal liability or punishment, and so on. Modern domestic legislation tends to increase the number of cases of release from liability or punishment. The Criminal Code of Ukraine provides for the following circumstances of release from criminal liability, namely in connection with: effective repentance (Article 45), reconciliation of the perpetrator with the victim (Article 46), transfer of a person on bail
Vol no 02 | no 01 | ISSN: 2675-7451

https://www.periodicojs.com.br/index.php/gei/index

(Article 47), change of circumstances (Article 48 ), the expiration of the statute of limitations (Article 49). Amnesty and pardon (Articles 8587) can be considered as a special type of exemption from criminal liability and punishment. By the way, the Code of Ukraine on Administrative Offenses provides the possibility of transferring materials on an administrative offense for consideration by a public organization or labour collective (Article 21) or the possibility of exemption from administrative liability in case of insignificance of the offense (Article 22). The application of the above measures illustrates the effect of the principle of humanism of legal responsibility. The principle of inevitability in this case is manifested in the obligation to inevitably apply measures of exemption from legal liability in cases provided by law. Violation of this principle will automatically lead to a violation of the principles of legality, expediency, humanism, individualization of legal responsibility, as well as hinder the achievement of the goals of this responsibility.

The constant emergence of new types of offenses necessitates a rethinking of the essence of the mechanism of legal liability and revision of its traditional goals. At present, it is important to recognize the restoration of the broken legal relationship as one of the main goals, while usually the punishment of the offender was brought to the fore. In today's world, it seems more effective to take the 
GÊNERO E

INTERDISCIPLINARIDADE

necessary measures to fulfill legal obligations by reconciling the parties than to demand satisfaction. A rational solution to a situation where a person voluntarily agrees to compensate for the damage caused before the application of punishment is to release him from legal liability.

The study of the institution of exemption from legal liability was initially carried out in the field of criminal and administrative law in connection with the exemption of mostly individuals from personal, moral and property restrictions. But later, thanks to economic and other reforms, the legal system is supplemented by a number of legal norms that define new grounds for exemption from legal liability. Thus, the institution of exemption from legal liability expands its boundaries, namely: begins to apply to legal entities; the mechanism of release from positive legal responsibility starts to develop, etc. Please note that the actual legal relationship in some cases does not agree with the legal grounds for exemption from legal liability: often the legal grounds for exemption from legal liability cannot be implemented in specific legal relationships due to lack of clear procedural mechanisms for their application at each stage. This, in turn, leads to a violation of the principle of inevitability of legal liability: the law enforcer violates the legal obligation of inevitably application of the institution of
Vol no 02 | no 01 | ISSN: 2675-7451

https://www.periodicojs.com.br/index.php/gei/index

exemption from legal liability in cases specified by applicable law.

\section{ASPECTS OF REGULATING THE MECHANISMS OF EXEMPTION FROM LEGAL LIABILITY AND THE PRINCIPLES OF INEVITABILITY}

The lack of a clear mechanism for regulating public and private interests in the implementation of legal liability creates a certain imbalance: there is no clear regulation of objective criteria for applying or not applying the grounds for exemption from legal liability, which leads to ineffective application of legal liability measures in general; the existing trends in law enforcement need to be adjusted to take into account public and private interests, as they currently contradict the principles of legal liability in some way, etc. In order to ensure the implementation of the principle of inevitability, it is necessary to formulate a definition of a comprehensive institution of legal liability, which will include such aspects as: the subject of regulation, system-forming features and intersystem connections inherent in this institution. Due to the dualism of views on the nature of legal liability, the recognition of its positive and negative aspects, it can be argued that their functions in the context of the institution of 
GÊNERO E

INTERDISCIPLINARIDADE

exemption from legal liability will differ in essence.

In the context of considering the negative aspect of legal liability, the institution of exemption from it can be defined as an independent comprehensive intersectoral institution that regulates legal relations arising from the state's refusal (expressed in the form prescribed by law) from a formal condemnation of the legal conduct of the offender in order to achieve the maximum effect on the correction or restoration of legal relations that were violated as a result of illegal actions, humanization and individualization of measures of influence and prevention of offenses. Attention should be paid to the grounds for exemption from legal liability the circumstances, the existence of which deprives the offender of the negative consequences for him of a personal, moral and property nature. By the way, it should be understood that the concepts of the grounds for release from legal liability, release from punishment and exclusion of legal liability are completely different in nature.

The lack of systematic legislative consolidation of the general features of determining the grounds for exemption from legal liability is explained by the lack of a single normative act in domestic legislation that would regulate the grounds for exemption from all types of legal liability. Therefore, for the effective application of the institution of
Vol no 02 | no 01 | ISSN: 2675-7451

https://www.periodicojs.com.br/index.php/gei/index

exemption from legal liability in compliance with the principle of inevitability, it would be necessary to derive general features of the grounds for exemption from legal liability for further application in the absence of such grounds in sectoral law. In the process of regulating the exemption from legal liability, legal norms and institutions, interacting with each other, must form a qualitatively new basis, which would be determined by establishing criteria for balancing public and private law, as in each case in the field of lawmaking and law enforcement there is a conflict of interest: on the one hand, the state seeks to implement the principle of inevitability of legal liability for each offense committed; on the other hand, the offender, in the absence of a fixed balance of interests and methods of substantiating the effectiveness of legal liability, using his legal right to protect his own interests, seeks to find grounds for release from legal liability, etc.

It should be noted that each branch of law, by its own means, solves the problem of exemption from legal liability. Along with the current norms, a comprehensive intersectoral institution of exemption from legal liability must contain a system forming a set of the following elements: principles, institutions (organizational moment), ideas, views (ideological moment). If we consider these elements in the dynamics, they will give the specified institution subject-functional nature, 
GENERO E

INTERDISCIPLINARIDADE

direct law-making and law-enforcement processes, filling with unity the dynamics of the emergence, change and termination of legal relations. You can agree with S.V. Medvedev (2005) that the essence of the legal structure of exemption from negative legal liability should be understood as the absence of a legal obligation to undergo measures of state coercion in the form of deprivation of personal, moral and property nature for the offense due to changes in its assessment and the subject of the offense as well as the subject of the offense on the grounds provided by law, in order to achieve a socially useful result.

This construction applies to all types of exemptions from legal liability, including its positive and negative aspects. Exemption from positive legal responsibility has specific features: exemption from it is carried out not only in the field of law enforcement, but also in regulatory relations, when the socially useful result is more in line with the interests of political goals of the state, ruling parties; exemption from positive responsibility is assessed not only legally but also politically, and is not always seen as a positive phenomenon due to the possible option of irresponsibility. In order to understand the essence of the process of release from legal liability, it is necessary to determine from which moment or stage of the legal relationship there is legal liability, because it is
Vol no 02 | no 01 | ISSN: 2675-7451

https://www.periodicojs.com.br/index.php/gei/index

impossible to release from what doesn't exist actually.

Given that the question of the moment of occurrence of legal liability is still debatable, the approaches of scientists to the moment of release from it also differ. Taking into account the analysis of legal concepts and constructions, the legal relationship of legal liability is inextricably linked with the offense, and release from it is possible at any stage of development of these legal relations, each of which ends with a legal event or action. Therefore, the institution of exemption from legal liability must be considered in the dynamics of the stages, taking into account the specifics of each of them.

Exemption from legal liability at the stage of its occurrence involves the identification of circumstances that preclude the possibility of prosecution, for example, due to insanity or failure to reach the age of legal responsibility. This stage corresponds to a related institution, namely the exclusion of legal liability, which makes it impossible to prosecute, although there are all grounds for this. Exemption from legal liability at the stage of concretization of legal liability takes place as a means of clarifying the circumstances of the case and the identity of the offender, such as effective repentance or expiration of the period of prosecution. In this case, it is a question of exemption from legal liability in the sense of the institution, which determines 
GÊNERO E

INTERDISCIPLINARIDADE

the conditions and circumstances provided by law, which determine the change of measures of influence. Exemption from legal liability at the stage of its implementation takes place after the fact of bringing a person to legal responsibility and provides for the release of a person from punishment, such as amnesty or pardon. At this stage, the institution of release from punishment is included in the work, which makes it impossible for the offender to undergo measures of state influence. After analyzing the three stages above, there is a need to compare such related concepts as the exclusion of legal liability, exemption from legal liability, exemption from punishment in order to clearly distinguish them.

Bringing a person to justice presupposes not only the existence of grounds for this, but also certain conditions. The fact that an offense has been committed does not necessarily mean that the person who committed it will necessarily bear legal responsibility, because there must be certain circumstances for a relationship of responsibility to arise. Thus, in order for a person to be subject to legal liability, he must have a sufficient level of consciousness, which is achieved at a certain age. After all, a person who has not reached the age from which he is able to realize the social significance of their actions, to understand their actual nature, to predict the consequences of their actions, cannot be held accountable before the law for the offense. A person must
Vol no 02 | no 01 | ISSN: 2675-7451

https://www.periodicojs.com.br/index.php/gei/index

also have an appropriate mental state that allows him to understand the meaning and significance of his actions, to anticipate their consequences and to wish (or not want) their occurrence. Persons, who suffer from a mental disorder, do not understand the meaning of their actions or cannot control them, go beyond the scope of legal liability.

The above does not allow to apply punishment to them, as it would be contrary to the spirit of law. However, the fact that the latter violated the rights of others still occurs, because there is a victim who was harmed, there is also a rule of law, the requirements of which were violated. And therefore, it is possible to speak that the offense was committed. In this case, the mentally ill person is not subject to legal liability. Therefore, the presence of an offense does not indicate the possibility of applying to it measures of state coercion. There is an offense in view of the violated legal norm, the violated right of a particular person and the damage caused as a result of this violation. In this case, there will be no subjective side of the illegal act - guilt in the form of intent or negligence, i.e. there is no corpus delicti, which excludes the possibility of bringing a person to justice. Also, in some cases, legal liability can arise only at the request of the person who was harmed, even if there is a corpus delicti.

If we consider such a legal construction as release from punishment, then there is a 
GÊNERO E

INTERDISCIPLINARIDADE

unity of views of scholars on the fact that release from punishment is applied within the implementation of legal liability and determines the circumstances that preclude the offender from state enforcement measures established by law for a particular offense. Given that punishment takes place only after the entry into force of the law enforcement act, therefore, release from punishment is possible only after its adoption, when legal liability has already begun to be exercised. And before the entry into force of this law enforcement act, we can talk about only exemption from legal liability. Thus, the essence of the legal structure of exemption from punishment can be defined as an element of the system of exemption from legal liability, which determines the circumstances or grounds provided by law that exclude the application of a sanction, the consequences of which for the offense he already suffers.

Given that, the basis for bringing to negative legal responsibility is the composition of the offense, so the release from it is solely due to changes in the assessment of the social significance of the elements of this composition through their legislative consolidation. Provided that the social assessment of the subject's actions remains unchanged, and the law provides circumstances that allow a milder assessment of the identity of the offender or his behaviour, there is a release from punishment: conviction
Vol no 02 | no 01 | ISSN: 2675-7451

https://www.periodicojs.com.br/index.php/gei/index

as a mandatory component of legal responsibility and measures of state influence remains unchanged, and only the punishment changes. Thus, release from legal liability always implies release from punishment, as there is a change in the characteristics of the illegality of the act itself. Exemption from punishment does not always imply exemption from other measures of legal responsibility, because the composition of the offense remains unchanged, and the offender's behaviour, even if he is not deprived of personal, organizational or property deprivation, is subject to conviction.

If we talk about the positive aspect of legal responsibility, then in this sense the institution of exemption from it will be considered as an element of legal policy, which stimulates the behaviour of legal entities through legal incentives, causing a certain socially significant result, thus contributing to the rule of law and civil society. Of course, the incentive will not only stimulate the desire of the subjects of legal relations to perform their legal duties with high quality due to the interest in achieving the desired result, but also indirectly, through the use of positive methods, deter anti-social and illegal behaviour. To date, when researching the issue of exemption from legal liability, none of the theoretical scholars has considered the issue of exemption from positive legal liability, in particular, on the own initiative of the subject of legal relations. It 
GÊNERO E

INTERDISCIPLINARIDADE

should be noted that such a legal phenomenon is currently quite common, and the institution of exemption from positive legal liability has clear legal regulations. Here are some examples.

Article 81 of the Constitution of Ukraine stipulates that the powers of MP of Ukraine shall be terminated prematurely in the event of their resignation upon his personal application. That is, the MP of Ukraine is released from the positive legal responsibility to inevitably perform the legal duties assigned to him by this special status. But he, of course, cannot free himself from the inevitable fulfillment of the legal obligation to act lawfully, not to violate the precepts of legal norms, from the obligation that inevitably arises in every citizen of our state with the acquisition of tort. The same situation occurs when according to Article 108 of the Constitution of Ukraine, the powers of the President of Ukraine in case of his resignation are terminated ahead of schedule.

An interesting example of exemption from positive legal liability is contained in Article 115 of the Constitution of Ukraine. The Cabinet of Ministers of Ukraine resigns before the newly elected President of Ukraine. In this case, it has a legal fact, i.e. the election of a new president. Ministers of the Cabinet of Ministers of Ukraine must inevitably perform their legal duties, defined by their special status, i.e. bear positive legal responsibility
Vol no 02 | no 01 | ISSN: 2675-7451

https://www.periodicojs.com.br/index.php/gei/index

during the term of the presidential powers under which the government was formed. From the moment of termination of the powers of the President of Ukraine, regardless of the will and desire of the members of the government, they are released from the inevitable performance of their legal obligations, i.e. exempt from positive legal liability. This article also stipulates that the Prime Minister of Ukraine and other members of the Cabinet of Ministers of Ukraine have the right to declare their resignation to the President of Ukraine and release themselves, thus, on their own initiative from positive legal liability under applicable law for legal entities who have such a special status.

The resignation of the Prime Minister of Ukraine entails the resignation of the entire Cabinet of Ministers of Ukraine. In this case, the Prime Minister of Ukraine, by voluntarily relieving himself of the positive legal responsibility of inevitably fulfilling his duties, automatically releases all members of his government from fulfilling their legal duties. The adoption by the Verkhovna Rada of Ukraine of a resolution of mistrust in the Cabinet of Ministers of Ukraine leads to the resignation of the Cabinet of Ministers of Ukraine. The release of members of the government from the responsibility of inevitably fulfilling the obligations provided by law is based on a legal fact, namely a 
GÊNERO E

INTERDISCIPLINARIDADE

resolution of mistrust, which does not depend on their will or interest.

In the Civil Code of Ukraine, for example, in Article 651 defines the grounds for changing or terminating the contract. Modification or termination of the contract is allowed only with the consent of the parties, unless otherwise provided by contract or law. The contract may be amended or terminated by a court decision at the request of one of the parties in the event of a material breach of contract by the other party and in other cases established by contract or law. After the conclusion of the contract and, in particular, during its execution, there may be a need to change or terminate it. The right to change or terminate the contract is a logical continuation of the freedom of the parties to enter into a contractual relationship and determine the content of the contract. As a general rule, change or termination of the contract is allowed only with the consent of the parties, unless otherwise provided by contract or law. Among the grounds for termination of obligations, the Civil Code calls the agreement of the parties, in particular, the agreement to replace the original obligation with a new obligation between the same parties (innovation - Article 604 of the Civil Code), the transfer of the debtor to the creditor. Thus, by amending or terminating the contract by agreement, the parties on their own initiative partially or completely release themselves
Vol no 02 | no 01 | ISSN: 2675-7451

https://www.periodicojs.com.br/index.php/gei/index

from positive legal liability, i.e. the inevitable performance of legal obligations arising from them as a result of the agreement.

The Civil Code of Ukraine illustrates another case of exemption from positive legal liability. Thus, in Articles 744 "The concept of a contract of lifetime maintenance (care)", 749 "Obligations of the purchaser under the contract of lifetime maintenance (care)", it is determined that the person-purchaser, concluding this agreement, assumes the responsibility to inevitably fulfill specified legal obligations. Exemption from positive legal liability, namely the alienator's retention, will occur regardless of the will of the acquirer after the death of the person undergoing lifelong care and the proper performance of all essential terms of the contract. That is, in this case we can talk about a legal fact (death of the alienator) as a basis for exemption from positive legal liability.

Article 105 of the Family Code of Ukraine determines the grounds for termination of marriage due to its dissolution. The marriage is terminated as a result of its dissolution upon a joint application of the spouses in accordance with Article 106 or one of them in accordance with Article 107 of this Code. Thus, the spouses jointly or at the request of one of them release themselves from the positive legal responsibility for the inevitable performance of their obligations arising from the moment of registration of 
GÊNERO E

INTERDISCIPLINARIDADE

marriage. Family Code of Ukraine in Article 180 "The duty of parents to maintain a child" regulates that parents are obliged to maintain a child until he or she reaches the age of majority. Thus, when a child reaches the age of 18, parents are legally released from the positive legal responsibility for the inevitable performance of their maintenance responsibilities, regardless of their desire. Article 188 of the Family Code of Ukraine "Exemption of parents from the obligation to maintain a child" stipulates that parents may be released from the obligation to maintain a child if the child's income far exceeds the income of each of them and fully meets its needs.

Code of Labour Laws of Ukraine according to Article 38 "Termination of an employment contract concluded for an indefinite period, at the initiative of the employee" and Article 39 "Termination of a fixed-term employment contract at the initiative of the employee" provides an opportunity for the employee to release himself from the duties assigned to him at will. From the moment a person is fired, he automatically ceases to bear positive legal responsibility for the inevitable performance of the work entrusted to him.

The study of the legal literature suggests the existence of different views on the essence of the principle of inevitability of legal liability, as well as the lack of special studies aimed at clarifying aspects of its relationship
Vol no 02 | no 01 | ISSN: 2675-7451

https://www.periodicojs.com.br/index.php/gei/index

with the institution of exemption from legal liability. Yes, A.V. Pomogalov

(2007) suggests that the concept of the principle of inevitability of legal responsibility, given the content and essence of modern legal understanding, should be disclosed through the concept of legal responsibility, because, in essence, it must already contain inevitability. We can agree with O.V. Ivanenko (2007) that legal responsibility is the subject's awareness of the right to his actions in the process of realization of the rights and responsibilities assigned to him, the will to act and the actual behaviour (action or inaction), which meets the requirements of the law (voluntary form of implementation), and as the possibility of experiencing certain restrictions in case of violation of law (compulsory form of implementation). A.Y. Shevchenko and O.L. Strelnyk (2012) note that the restorative function is equally inherent in different types of legal liability. The result of the impact of the restorative function of legal liability contains two aspects. The first involves the restoration of law and order, legality, legal relations, the second - the restoration of social relations, social justice, psychological peace of society. In addition, it is believed that legal liability for violations of the law is a kind of social responsibility for violations of various social norms (Onishchenko, 2012).

Some researchers have paid attention to the study of a positive form of legal liability. 
In particular, V.A. Yeleonskyi (1979) argues that its source is legal norms. With positive responsibility, sanctions are an incentive for positive behaviour. A.V. Malko (1997) argues that the legal institution of encouragement is, above all, an incentive to take legal action and can be seen as an argument in favour of the existence of a voluntary (positive) form of legal liability. D.A. Lypynsky (1999) adds that encouragement is directly related to the performance of duties, with the awareness of the subject of their actions and is realized in real lawful behaviour. Y.M. Oborotov (2011) argues that positive legal responsibility is a type of legal responsibility, which is a corresponding reaction of the state and society to the socially useful lawful act of a person in the form of application of various legal incentives. Finally, the need to include in the positive form of legal liability legal incentives, benefits and incentives insist E.V. Biloziorov, Y.O. Gida, A.M. Zavalny, A.O. Osaulenko, T.O. Pikulya (2010), as well as A.Y. Shevchenko and S.V. Kudin (2016).

Most discussions in the scientific literature have unfolded about understanding the essence of the principle of inevitability of legal liability. Thus, one group of scholars connects the inevitability of liability with the mandatory application of punishment or other measures of criminal law influence (Bazylev, 1985), V.N. Kudryavtsev (1986). Others see the content of this principle as
Vol no 02 | no 01 | ISSN: 2675-7451

https://www.periodicojs.com.br/index.php/gei/index

mandatory disclosure of offenses, conviction of the guilty person, appointment and execution of punishment (Belyaev, 1986). There is also a group of supporters of the awareness of the principle of inevitability of legal liability through the mandatory influence of the competent authorities on the offender (Molodtsov and Blagov, 1984).

According to N.V. Vanteeva (2005) the principle of inevitability of legal liability must be observed at all stages of its implementation, and therefore the components of its content should include the following requirements: mandatory detection, disclosure of all offenses and bringing perpetrators to justice; application of specific measures of legal responsibility to the guilty persons; direct implementation of these measures, etc. The implementation of the principle of inevitability of legal liability in each case, in her opinion, is possible only in the presence of these components at the same time.

Some researchers have tried to consider the principle of inevitability in connection with the mutual responsibility of all subjects of law, which exists both vertically and horizontally, i.e. between the state and the citizen, and citizens among themselves (Matuzov, 1996; Mironenko, 2001). A separate opinion was expressed by L.V. Golovko (2002), who argues that such a principle does not exist at all, citing the lack of its direct legislative enshrinement. The study of the institution of 
GÊNERO E

INTERDISCIPLINARIDADE

exemption from legal liability was initially carried out in the field of criminal and administrative law in connection with the exemption of mostly individuals from personal, moral and property restrictions. Subsequently, exemption from legal liability in jurisprudence began to be considered as an independent comprehensive interdisciplinary institution that regulates legal relations arising from the refusal of the state to officially condemn the legal conduct of an entity that committed an offense or failed to fulfill its statutory liability expressed in the form prescribed by law (Medvedev, 2005).

Note that clarifying the nature of the exclusion of legal liability is controversial among scholars. It is considered that the exclusion of legal liability is a concept incompatible with release from legal liability, as release is possible only in the implementation of legal liability for the offense, i.e. an act that contains all the statutory features of the offense. In the absence of an offense, there is no responsibility for it, so it makes no sense to talk about release from legal liability. Thus, circumstances that exclude the criminality of the act, such as insanity, necessary defence, extreme necessity, not reaching the age of legal responsibility, are not grounds for exemption from legal liability, and should be considered as circumstances that exclude the criminality and punishment of the act (Endoltseva, 2004). There is also an
Vol no 02 | no 01 | ISSN: 2675-7451

https://www.periodicojs.com.br/index.php/gei/index

opinion that the concept of "exclusion of legal liability" due to its ambiguity can be used in a broad (preventing the existence, occurrence of something) and narrow (termination of something) meaning (Shevchenko et al., 2011; Shevchenko et al., 2015).

\section{CONCLUSIONS}

The essence of the principle of inevitability of legal liability is to ensure the effectiveness of the law, the effectiveness of its impact on human behaviour, as well as the inevitable occurrence of legal liability in the absence of grounds for exemption from it. The study of the principle of inevitability should be based on an understanding of the dualistic nature of legal liability, namely the combination of its positive and negative forms of implementation. Therefore, the positive form of realization of legal responsibility should be considered as a way to ensure the legal obligation (necessity) of the subjects of law to implement the provisions of legal norms, which is outwardly manifested in their lawful behaviour, which is encouraged and approved by the state; negative - as a way of legislative provision of the need for the offender to fulfill the obligations to deprive him of certain social benefits in connection with the application of coercive measures of negative influence. 
GÊNERO E

INTERDISCIPLINARIDADE

The principle of inevitability of legal liability is presented as a fundamental idea of the functioning of this interdisciplinary institution, which is mandatory compliance with legal norms by lawful conduct of legal entities (positive aspect), the response of authorized bodies (officials) to the facts of offenses, offenders (negative aspect), as well as the need for legal consequences as a result of a fair response. The essence of the principle of inevitability of legal liability is to ensure the effectiveness of law; the effectiveness of its influence on the behaviour of the subjects of legal relations; efficiency of the institute of legal responsibility in the mechanism of legal regulation; creating guarantees for the realization of subjective rights and legal obligations; ensuring the protection of guaranteed human and civil rights and freedoms; embodiment of the ideals of a fair model.

The main requirements of the principle of inevitability of legal liability, which form its content, are: the inevitable performance of the subjects of law of their legal obligations; a combination of persuasion and coercion aimed at ensuring the proper performance of legal duties and, consequently, legal responsibility itself; mandatory compliance with the implementation of positive and negative forms of legal liability; ensuring the unavoidable implementation of legal obligations due to their clear legal regulation and strict control by
Vol no 02 | no 01 | ISSN: 2675-7451

https://www.periodicojs.com.br/index.php/gei/index

the state. Exemption from legal liability always implies exemption from punishment, but not vice versa. And the exclusion of legal liability implies its non-application, and therefore cannot be considered any of the forms or stages of exemption from it.

The methodological significance of the legal construction of the principle of inevitability in connection with the release from legal liability in its positive and negative contexts of understanding is: in the negative aspect a person has an obligation not to be subject to personal, organizational or material restrictions and then act lawfully; on the positive side, the person is deprived of the inevitable obligation to perform legal obligations, but is not deprived of the obligation to act exclusively lawfully. A comprehensive institution of exemption from legal liability can be considered as a set of rules of various branches of law that govern the goals, principles, grounds, conditions, limits, forms, the process of their application. The principle of inevitability and the institution of exemption from legal liability are interrelated and complementary. The existence of the institution of exemption from legal liability in no way contradicts the principle of inevitability and, moreover, cannot impede its implementation, provided that there is no abuse in the application of exemption from legal liability. Realization of the institute of release from legal responsibility is possible 
GÊNERO E

INTERDISCIPLINARIDADE

only on condition of observance of the principle of inevitability of the specified responsibility.

\section{References}

Babayev, V.K. Theory of state and law. Moscow: Yurist, 1999.

Baulin, Y.V. Legal liability: problems of exclusion and dismissal. the team of authors. Donetsk: PE "VD Kalmius", 2013.

Bazylev, B.T. Legal Responsibility (Theoretical Questions). Krasnoyarsk: Krasnoyarsk University, 1985.

Belyaev, N.A. Criminal law policy and ways of its implementation. Leningrad: LSU, 1986.

Bilozyorov, E.V. Gida, E.O., Zavalny A.M. Current issues of the theory of state and law. Kyiv: Private entrepreneur O.S. Lipkan, 2010.

Endoltseva, A.V. The institute of exemption from criminal liability: problems and ways to solve them. Moscow: UNITY - DANA; Order and law, 2004.

Golovko, L.V. Alternatives to Criminal Prosecution in Modern Law. Moscow: Legal Centre Press, 2002.

Golovko, L.V. Principles of inevitability of responsibility and publicity in modern Russian criminal law and process. State and Law, 1999, 3: 61-68.
Vol no 02 | no 01 | ISSN: 2675-7451

https://www.periodicojs.com.br/index.php/gei/index

Ivanenko, O.V. The essence of legal responsibility and the role of law enforcement agencies in its provision. Kyiv: Kyiv National University of Internal Affairs, 2007.

Korelsky, V.M., and Perevalov, V.D. Theory of state and law. Moscow: NORMA-INFRA, 2000 .

Kudryavtsev, V.N. Law, deed, responsibility. Moscow: Nauka. 1986.

Lazarev, V.V. General theory of law and the state. Moscow: Yurist. 1999.

Lypynsky, D.A. Forms of realization of legal responsibility. Togliatti: VUiT Publishing House. 1999.

Malko, A.V. Theory of the state and law in questions and answers. Moscow: Yurist, 1997.

Matuzov, N.I. Human rights and general regulatory relations. University News. Jurisprudence, 1996, 3: 42-46.

Medvedev, S.V. Exemption from legal liability in the Russian state: (Theoretical and Practical Aspects). Nizhny Novgorod: Nizhny Novgorod Academy of the Ministry of Internal Affairs of Russia, 2005.

Mironenko, M.B. Principles of legal responsibility in the system of principles of law. Saratov: Samara State Academy. 2001.

Molodtsov, A.S., and Blagov, E.S. About the norm of criminal law and the principle of inevitability of realization of responsibility for 
GÊNERO E

INTERDISCIPLINARIDADE

the committed crime. In Problems of Inevitability of Responsibility in Criminal Law and Process: A Collection of Scientific Works (pp. 36-42). Kaliningrad: Kaliningrad University, 1984.

Oborotov, Y.N. General Theoretical jurisprudence. Odesa: Phoenix. 2011.

Onishchenko, N.M. Normative tactics as a component of state and legal policy. Bulletin of the Ministry of Justice of Ukraine, 2012, 4(126): 37-42.

Pomogalov, A.V. The inevitability of legal liability as a principle of legality. Moscow: Moscow University of the Ministry of Internal Affairs of Russia. 2007.

Shevchenko, A.Y., Solovyova, V.V., Strelnik, O.L. Circumstances precluding legal liability. Donetsk: Southeast, 2011.

Shevchenko, A.Y., Starostyuk, A.V., Karmalita, M.V. Theory of state and law. Vinnytsia: Nilan Ltd, 2015.

Shevchenko, A.Y., Strelnik, O.L. Restorative function of legal responsibility. Public Law, 2012, 4: 269-275.

Shevchenko, A.Y., Topchiy, V.V., Kudin, S.V. Current issues of the theory of state and law. Irpin: SFS University of Ukraine. 2016.

Sobolev, V., and Potapenko, S. Fear of acquittals: its roots. Russian Justice, 1989, 10: 8-19.
Vol no 02 | no 01 | ISSN: 2675-7451

https://www.periodicojs.com.br/index.php/gei/index

Vanteeva, N.V. Principles of legal responsibility (Structural and Logical Analysis). Yaroslavl: Yaroslavl State University P. G. Demidova, 2005.

Vasilieva, E.G. Coercive measures. Ufa: BashSU, 2003.

Yeleonskyi, V.A. Criminal punishment and education of positive responsibility of the person. Ryazan: Publishing house of the RHS of the Ministry of Internal Affairs of the USSR, 1979. 